\title{
Phenylethylpyranone and Aristolochic Acid Derivatives from Aristolochia urupaensis
}

\author{
Juliana C. Holzbach, Isabele R. Nascimento* and Lucia M. X. Lopes \\ Instituto de Química, Universidade Estadual Paulista (Unesp), CP 355, 14800-060 Araraquara-SP, Brazil
}

\begin{abstract}
A new pyranone, $(S)$-2-(4-hydroxyphenylethyl)-6-methyl-2,3-dihydro-4H-pyran-4-one, with unusual carbon skeleton, and three new aristolochic acid derivatives (7- $O$-methylaristolochic acid $\mathrm{F}$, sodium 7-O-methylaristolochate $\mathrm{F}$ and sodium aristolochate $\mathrm{F}$ ) were isolated from Aristolochia urupaensis (Aristolochiaceae) stems together with 31 known compounds. The structures of the compounds were determined by spectroscopic analyses, including Fourier transform infrared (FTIR) and 1D and 2D nuclear magnetic resonance (NMR) techniques, and high-resolution mass spectrometry (HRMS).
\end{abstract}

Keywords: Aristolochia urupaensis, Aristolochiaceae, sodium aristolochate, phenylethylpyranone

\section{Introduction}

Aristolochia is the largest genus of the family Aristolochiaceae with about 500 species worldwide and 92 native species to Brazil. ${ }^{1,2}$ The interest in phytochemical studies on Aristolochia is due to the extensive use of its species in traditional and homeopathic medicine. ${ }^{3}$ According to Heirinch et al. ${ }^{4} 99$ species of Aristolochia have been reported for medicinal uses, including for treatment of sexually transmitted diseases (STDs), gastrointestinal complaints, snakebites and poisoning, eczema and fungal skin diseases, as well as abortifacient. Many studies on Aristolochia species are linked to aristolochic acid nephropathy (AAN), a disease associated with kidney failure and upper urothelial carcinoma (UUC). Although aristolochic acids I and II (AAs) are considered to be responsible for these nephrotoxic and carcinogenic effects, ${ }^{5}$ other aristolochic acids and aristolactams, also present in these species, may be considered as nephrotoxic agents. ${ }^{6,7}$

In continuation to previous chemical studies on plants belonging to the Aristolochiaceae family, we report the isolation and structural elucidation of 35 compounds (Figure S1 in the Supplementary Information (SI) section) from the stems of Aristolochia urupaensis Hoehne. Among them, a pyranone, an aristolochic acid and two sodium aristolochates were isolated and identified for the first time. The known compounds were identified by comparing their

*e-mail: isabnasc@iq.unesp.br physical and spectroscopic data with those of authentic samples and/or data reported in the literature.

\section{Experimental}

General experimental procedures

One-dimensional $\left({ }^{1} \mathrm{H},{ }^{13} \mathrm{C}\right.$ and TOCSY (total correlation spectroscopy)) and two-dimensional $\left({ }^{1} \mathrm{H}-{ }^{1} \mathrm{H}\right.$ COSY (homonuclear correlation), HSQC (heteronuclear singlequantum correlation) and HMBC (heteronuclear multiple bond correlation) NMR (nuclear magnetic resonance) experiments were performed on a Bruker Avance III 600 spectrometer $(14.1 \mathrm{~T})$ at $600 \mathrm{MHz}\left({ }^{1} \mathrm{H}\right)$ and $151 \mathrm{MHz}$ $\left({ }^{13} \mathrm{C}\right)$, using deuterated solvents $\left(\mathrm{CDCl}_{3}\right.$ and DMSO- $\left.d_{6}\right)$ $\left(99.98 \%\right.$ D) as internal standards for ${ }^{13} \mathrm{C}$ NMR chemical shifts and residual solvent as an internal standard for ${ }^{1} \mathrm{H}$ NMR. $\delta$ values are reported relative to TMS (tetramethylsilane). High-resolution mass spectra (HRMS) were obtained on a Q-TOF Bruker MaXis Impact ${ }^{\mathrm{TM}}$ mass spectrometer. Fourier transform infrared (FTIR) spectra were obtained on a Bruker VERTEX 70 FTIR spectrometer using ATR (attenuated total reflectance). Optical rotations were measured on a PerkinElmer 341-LC polarimeter. Ultraviolet (UV) absorptions were measured on a PerkinElmer UV-Vis Lambda 1050. Circular dichroism (CD) spectra were recorded on a JASCO J-815 spectrometer, using $1.0 \mathrm{~mm}$ cell. High performance liquid chromatography (HPLC) analyses were performed using a Jasco LC-NetII/ADC, equipped with photodiode array 
(MD-2018 Plus) and CD (2095 Plus) detectors. A Zorbax RX C18 $(5 \mu \mathrm{m}, 250 \times 9.4 \mathrm{~mm}$, Agilent $)$ and Microsorb $100 \AA ̊$ Phenyl $(5 \mu \mathrm{m}, 250 \times 4.6 \mathrm{~mm}$, Agilent $)$ columns were used for semi-preparative analysis. Solvents were HPLC grade from Mallinckrodt. Ultrapure water was obtained from Direct-Q3 UV System from Millipore.

\section{Plant material}

The plant materials (stems and leaves) were collected in the city of Porto Nacional (Tocantins State, Brazil) in December 2014, and identified as Aristolochia urupaensis Hoehne by Dr Vinicius Castro Souza and MSc Joelcio Freitas. A voucher specimen (MBML 50517, 28/07/2016) was deposited at the herbarium of Museu de Biologia Prof Mello Leitão (MBML) in the city of Santa Teresa (Espírito Santo State, Brazil). The materials were separated according to the plant parts and dried (ca. $45^{\circ} \mathrm{C}$ ).

\section{Extraction and isolation}

The stems (194.7 g) were ground and exhaustively extracted by maceration at room temperature with hexanes, acetone and ethanol $(3 \times$ ca. $200 \mathrm{~mL}, 48 \mathrm{~h}$, and shaken manually every $12 \mathrm{~h}$ for 2 min for each extraction), successively. Then, the residue was extracted with ethanol in a Soxhlet apparatus and extracts were individually concentrated.

The crude ethanol extract $(3.5 \mathrm{~g})$ was washed with methanol. The insoluble fraction gave $\mathbf{3 3}(530.0 \mathrm{mg})$. The soluble fraction was concentrated $(3.0 \mathrm{~g})$ and subjected to the column chromatography $(\mathrm{CC})(\mathrm{C} 18,18.7 \times 3.0 \mathrm{~cm}$, $\mathrm{H}_{2} \mathrm{O}-\mathrm{MeOH}$ gradient, 9:1 to $\left.100 \% \mathrm{MeOH}\right)$ to give 11 fractions (ca. $100 \mathrm{~mL}$ each; Fr1-Fr11). Fr6 gave 2 $(21.7 \mathrm{mg})$. Fr2, Fr4, Fr5, Fr9 and Fr10 were subjected to $\mathrm{C} 18$ prep-HPLC by using different $\mathrm{H}_{2} \mathrm{O}-\mathrm{MeOH}$ gradients for further separation. Fr2 gave $\mathbf{2 5}+\mathbf{3 4}(2.0 \mathrm{mg}), \mathbf{2 6}(0.9 \mathrm{mg})$ and $\mathbf{3 4}(1.0 \mathrm{mg})$; Fr4 gave $\mathbf{1 0}(0.3 \mathrm{mg}), \mathbf{2 1}(0.5 \mathrm{mg}), \mathbf{2 7}+\mathbf{3 0}$ $(0.5 \mathrm{mg})$ and $\mathbf{2 8}+\mathbf{3 1}(0.4 \mathrm{mg})$; Fr5 gave $\mathbf{1 8}+\mathbf{2 0}(0.4 \mathrm{mg})$, 19 (3.9 mg), $22(0.7 \mathrm{mg})$ and $\mathbf{2 3}(0.5 \mathrm{mg}) ; \mathrm{Fr} 9$ gave $\mathbf{3}$ (1.4 mg), 4 + 5 (1.2 mg), 7 (0.7 mg), $8(0.8 \mathrm{mg}), \mathbf{9}(1.1 \mathrm{mg})$ and $\mathbf{1 5}(2.5 \mathrm{mg})$; and Fr10 gave $\mathbf{3}(0.3 \mathrm{mg})$ and $\mathbf{1 1}(0.2 \mathrm{mg})$. The mixture $\mathbf{4}+\mathbf{5}$ was subjected to HPLC by using phenyl column and eluted with $\mathrm{H}_{2} \mathrm{O}-\mathrm{ACN}$ 11:9 to give $\mathbf{5}(0.4 \mathrm{mg})$.

The crude ethanolic Soxhlet extract $(7.7 \mathrm{~g})$ was fractioned on Amberlite XAD-16 column eluting with $\mathrm{H}_{2} \mathrm{O}(600 \mathrm{~mL}), \mathrm{MeOH}(300 \mathrm{~mL})$ and EtOAc $(200 \mathrm{~mL})$, successively. The $\mathrm{MeOH}$ portion was concentrated $(1.5 \mathrm{~g})$ and subjected to $\mathrm{CC}(\mathrm{C} 18,13.0 \times 1.0 \mathrm{~cm}$, $\mathrm{H}_{2} \mathrm{O}-\mathrm{MeOH}$ gradient, 9:1 to $100 \% \mathrm{MeOH}$ ) to give 12 fractions (ca. $100 \mathrm{~mL}$ each; Fr1-Fr12). Fr1 and Fr9 gave $33(26.3 \mathrm{mg})$ and $\mathbf{3}(87.2 \mathrm{mg})$, respectively. Fr7, Fr8 and Fr10 were subjected to C18 prep-HPLC by using different $\mathrm{H}_{2} \mathrm{O}-\mathrm{MeOH}$ gradients for further separation. Fr7 gave $\mathbf{1}(1.0 \mathrm{mg}), \mathbf{2}(1.0 \mathrm{mg}), \mathbf{6}(1.1 \mathrm{mg}), \mathbf{6}+\mathbf{9}(1.0 \mathrm{mg})$, $12+13(1.0 \mathrm{mg}), \mathbf{1 6}(0.7 \mathrm{mg}), \mathbf{2 4}(1.2 \mathrm{mg})$ and $29+32$ $(0.3 \mathrm{mg})$. Fr8 gave $\mathbf{2}(1.0 \mathrm{mg}), \mathbf{9}(0.7 \mathrm{mg}), \mathbf{1 4}(0.2 \mathrm{mg})$ and $\mathbf{1 6}(0.5 \mathrm{mg})$, and Fr10 gave $\mathbf{3}(1.0 \mathrm{mg}), \mathbf{1 1}(0.6 \mathrm{mg})$, $\mathbf{1 7}(0.2 \mathrm{mg})$ and $\mathbf{3 5}(0.9 \mathrm{mg})$.

(-)-(S)-2-(4-Hydroxyphenylethyl)-6-methyl-2,3-dihydro4H-pyran-4-one (1)

Yellow amorphous powder; $[\alpha]_{\mathrm{D}}^{28}-12.9(c 0.001, \mathrm{MeOH})$; $\mathrm{CD}(c$ 0.0107, $\mathrm{MeOH})[\Theta]_{270}-131826,[\Theta]_{318}-202997$;

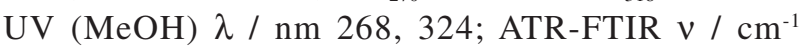
3386,1647 ; ${ }^{1} \mathrm{H}$ NMR $\left(600 \mathrm{MHz}\right.$, DMSO- $\left.d_{6}\right) \delta 1.85$ (dddd, 1H, J 13.1, 9.0, 5.6, $4.4 \mathrm{~Hz}, \mathrm{H}-1$ 'a), 1.97 (dddd, 1H, $J$ 13.1, 9.6, 8.1, 5.9 Hz, H-1'b), 1.98 (br s, 3H, H-7), 2.31 (ddd, 1H, $J$ 16.8, 3.7, $0.7 \mathrm{~Hz}, \mathrm{H}-3 \mathrm{a}$ ), 2.40 (dd, 1H, $J$ 16.8, $13.2 \mathrm{~Hz}, \mathrm{H}-3 \mathrm{~b}$ ), 2.58 (ddd, $1 \mathrm{H}, J$ 13.1, 9.0, $5.9 \mathrm{~Hz}, \mathrm{H}-2$ ' a), 2.64 (ddd, 1H, J 13.1, 9.6, 4.4 Hz, H-2'b), 4.32 (dddd, 1H, $J$ 13.2, 8.1, 5.6, $3.7 \mathrm{~Hz}, \mathrm{H}-2$ ), 5.26 (br s, 1H, H-5), 6.67 (d, 2H, J 8.4, H-3"/5"), 7.00 (d, 2H, J $8.4 \mathrm{~Hz}, \mathrm{H}-2 " / 6 ")$; ${ }^{13} \mathrm{C}$ NMR (151 MHz, DMSO- $\left.d_{6}\right) \delta 20.8$ (C-7), 29.7 (C-2'), 35.8 (C-1'), 40.3 (C-3), 78.4 (C-2), 104.4 (C-5), 115.3 (C-3"/5"), 129.4 (C-2"/6"), 131.3 (C-1"), 155.6 (C-4"), 174.2 (C-6), 192.1 (C-4); HRMS (ESI QTOF, positive mode) $\mathrm{m} / z$ (rel. int.): $233.1175[\mathrm{M}+\mathrm{H}]^{+}$(100) (calcd. for $\mathrm{C}_{14} \mathrm{H}_{17} \mathrm{O}_{3}, 233.1178$ ).

\section{7-O-Methylaristolochic acid $\mathrm{F}$ (5)}

Yellow oil; UV (MeOH) $\lambda / \mathrm{nm} \mathrm{264,} \mathrm{308,} \mathrm{380;}$ ATR-FTIR $v / \mathrm{cm}^{-1} 1340,1521,1699,3145 ;{ }^{1} \mathrm{H}$ and ${ }^{13} \mathrm{C}$ NMR data, see Table 1; HRMS (ESI QTOF, positive mode) $\mathrm{m} / z$ (rel. int.): $342.0610[\mathrm{M}+\mathrm{H}]^{+}$(45), 298.0707 $\left[\mathrm{M}+\mathrm{H}-\mathrm{CO}_{2}\right]^{+}(100)$ (calcd. for $\mathrm{C}_{17} \mathrm{H}_{12} \mathrm{NO}_{7}, 342.0613$ ).

\section{Sodium 7-O-methylaristolochate $\mathrm{F}(\mathbf{8})$}

Yellow amorphous powder; UV (MeOH) $\lambda / \mathrm{nm} 260$, 308, 376; ATR-FTIR $v / \mathrm{cm}^{-1} 1350,1590 ;{ }^{1} \mathrm{H}$ and ${ }^{13} \mathrm{C}$ NMR data, see Table 1; HRMS (ESI QTOF, positive mode) $\mathrm{m} / \mathrm{z}$ (rel. int.): $364.0428[\mathrm{M}+\mathrm{H}]^{+}(20), 342.0608[\mathrm{M}+\mathrm{H}-\mathrm{Na}]^{+}$ (35) (calcd. for $\mathrm{C}_{17} \mathrm{H}_{11} \mathrm{NO}_{7} \mathrm{Na}, 364.0428$ ).

\section{Sodium aristolochate $F(\mathbf{9})$}

Yellow amorphous powder; UV (MeOH) $\lambda / \mathrm{nm} 268$, 308, 376; ATR-FTIR $v / \mathrm{cm}^{-1} 1360,1542,1591,3240 ;{ }^{1} \mathrm{H}$ and ${ }^{13} \mathrm{C}$ NMR data, see Table 1; HRMS (ESI QTOF, positive mode) $\mathrm{m} / z$ (rel. int.): $350.0268[\mathrm{M}+\mathrm{H}]^{+}$(40) (calcd. for $\mathrm{C}_{16} \mathrm{H}_{9} \mathrm{NO}_{7} \mathrm{Na}$, 350.0271); HRMS (ESI QTOF, negative mode) $\mathrm{m} / z$ (rel. int.): $326.0315[\mathrm{M}-\mathrm{Na}]^{-}(100)$ (calcd. for $\mathrm{C}_{16} \mathrm{H}_{8} \mathrm{NO}_{7}, 326.0300$ ). 


\section{Results and Discussion}

Compounds 1-35 (Figure S1, in the SI section) were isolated from the ethanolic and ethanolic Soxhlet extracts of the stems by column chromatography followed by semipreparative HPLC. The structures of the known compounds were determined by comparison of their physical and spectroscopic data with those of authentic samples and/ or data reported in the literature. The known compounds were identified as aristolochic acid IIIa (2), aristolochic acid II (3), aristolochic acid I (4), ${ }^{8}$ sodium aristolochate IIIa (6), sodium aristolochate II (7), aristolactam IIIa $N$ - $\beta$-glucoside (10), ${ }^{9}$ aristolactam II (11), ${ }^{10}$ cepharanone A $\mathrm{N}$ - $\beta$-glucoside (12), ${ }^{11}$ aristolactam IIIa (13), ${ }^{12}$ aristolactam AII (14), ${ }^{13}$ cepharadione A (15), ${ }^{14}$ tuberosinone $(\mathbf{1 6}),{ }^{15}$ magnoflorine (17), trans- $N$-feruloyltyramine (18), trans- $N$-feruloyl-3-O-methyldopamine (19), cis- $N$-feruloyltyramine $(\mathbf{2 0}),{ }^{16}$ quercetin3 - $O$ - $\beta$-glucopyranosyl- $(1 \rightarrow 6)-\beta$-glucopyranoside $(\mathbf{2 1}),{ }^{17}$ quercetin-3- $O$ - $\beta$-glucopyranoside (22), ${ }^{18}$ kaempferol3-O- $\beta$-glucopyranosyl- $(1 \rightarrow 6)-\beta$-glucopyranoside $(\mathbf{2 3}),{ }^{19}$ tiliroside (24), ${ }^{20}$ icariside $\mathrm{D}_{2}$ (25), ${ }^{21}$ tyrosol1 - $O$ - $\beta$-xylopyranosyl- $(1 \rightarrow 6)-O$ - $\beta$-glucopyranoside $(\mathbf{2 6}),{ }^{22}$ trans-ferulic acid (27), ${ }^{23}$ trans-6-O-( $p$-coumaroyl)glucopyranoside $(\mathbf{2 8}),{ }^{24}(E)$-ethyl $p$-coumarate (29), ${ }^{25}$ cis-ferulic acid (30), ${ }^{23}$ cis-6-O-( $p$-coumaroyl)glucopyranoside $(\mathbf{3 1}),{ }^{24}(Z)$-ethyl $p$-coumarate $(\mathbf{3 2}),{ }^{25}$ $(R)$-allantoin $(\mathbf{3 3}),{ }^{9}$ adenosine (34) ${ }^{26}$ and (-)-9, $9^{\prime}$-di- $[O-(E)$ feruloyl] secoisolariciresinol (35). ${ }^{27}$ The flavonoids 21-23, the glycosidic phenylpropanoid $\mathbf{2 6}$ and the lignan $\mathbf{3 5}$ are being reported for the first time in the Aristolochiaceae family.

Compound 1 showed UV absorption bands at 268 and $324 \mathrm{~nm}$, and IR absorption bands at 1647 and $3386 \mathrm{~cm}^{-1}$ characteristics of $\alpha, \beta$-unsaturated ketone and hydroxyl group, respectively. The HRMS spectrum of $\mathbf{1}$ showed peak at $m / z 233.1175[\mathrm{M}+\mathrm{H}]^{+}$for protonated molecule, indicating the molecular formula $\mathrm{C}_{14} \mathrm{H}_{16} \mathrm{O}_{3}$ (calcd. for $\left.\mathrm{C}_{14} \mathrm{H}_{17} \mathrm{O}_{3}, 233.1178\right)$. The ${ }^{1} \mathrm{H}$ NMR and HSQC spectra showed signals for an aromatic ring 1,4-substituted

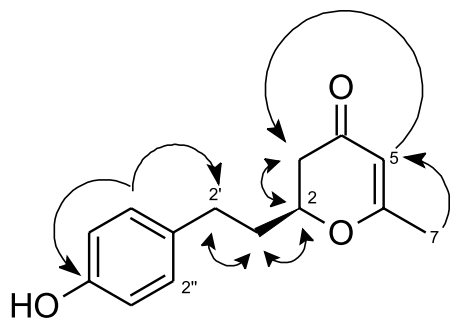

1

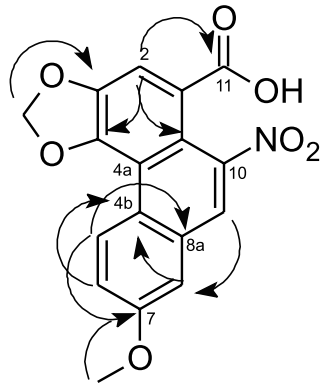

5

$\left(\delta_{\mathrm{H}} 7.00 \mathrm{~d}, J 8.4 \mathrm{~Hz}, 2 \mathrm{H}, \delta_{\mathrm{C}} 129.4\right.$ and $\delta_{\mathrm{H}} 6.67 \mathrm{~d}, J 8.4 \mathrm{~Hz}$, $\left.2 \mathrm{H}, \delta_{\mathrm{C}} 115.3\right)$, one olephinic $\mathrm{CH}\left(\delta_{\mathrm{H}} 5.26 \mathrm{br} \mathrm{s} ; \delta_{\mathrm{C}} 104.4\right)$, one carbinolic $\mathrm{CH}\left(\delta_{\mathrm{H}} 4.32\right.$ dddd, $J 13.2,8.1,5.6,3.7 \mathrm{~Hz}$; $\left.\delta_{\mathrm{C}} 78.4\right)$ and one methyl $\left(\delta_{\mathrm{H}} 1.98 \mathrm{br} \mathrm{s} ; \delta_{\mathrm{C}} 20.8\right)$ groups. In addition, three non-equivalent methylenes were observed $\left(\delta_{\mathrm{H}} 2.40 \mathrm{dd}, J 16.8,13.2 \mathrm{~Hz}\right.$ and $\delta_{\mathrm{H}} 2.31 \mathrm{ddd}, J 16.8,3.7$, $0.7 \mathrm{~Hz}, \delta_{\mathrm{C}} 40.3, \mathrm{CH}_{2}-3 ; \delta_{\mathrm{H}} 1.97 \mathrm{dddd}, J 13.1,9.6,8.1,5.9 \mathrm{~Hz}$ and $\delta_{\mathrm{H}} 1.85 \mathrm{dddd}, J 13.1,9.0,5.6,4.4 \mathrm{~Hz}, \delta_{\mathrm{C}} 35.8, \mathrm{CH}_{2}-1$ '; and $\delta_{\mathrm{H}} 2.64 \mathrm{ddd}, J 13.1,9.6,4.4 \mathrm{~Hz}$ and $\delta_{\mathrm{H}} 2.58 \mathrm{ddd}, J 13.1$, 9.0, $5.9 \mathrm{~Hz}, \delta_{\mathrm{C}} 29.7, \mathrm{CH}_{2}-2$ '). The multiplicities of the methylene hydrogens were determined with the help of spectral simulations using the WINDNMR-Pro program ${ }^{28}$ (Figure S3, in the SI section). ${ }^{1} \mathrm{H}-{ }^{1} \mathrm{H}$ COSY experiment showed correlations between $\mathrm{H}-3$ and $\mathrm{H}-2$, as well as between H-1' and H-2' and H-2 (Figure 1). The correlations observed by HMBC experiment between C-2' $\left(\delta_{\mathrm{C}} 29.7\right)$ and $\mathrm{H}-2 ", 6 "\left(\delta_{\mathrm{H}} 7.00\right)$; C-3 $\left(\delta_{\mathrm{C}} 40.3\right)$ and $\mathrm{H}-5\left(\delta_{\mathrm{H}} 5.26\right)$; $\mathrm{C}-5\left(\delta_{\mathrm{C}} 104.4\right)$ and $\mathrm{H}-7\left(\delta_{\mathrm{H}} 1.98\right)$, as well as the molecular formula determined for this compound led to establishing of a 2-(4-hydroxyphenylethyl)-6-methyl-2,3-dihydro$4 H$-pyran-4-one structure for 1 (Figure 1), which was confirmed by correlations between $\mathrm{H}-2$ and $2 \mathrm{H}-3,2 \mathrm{H}-1$ ', and 2H-2' observed by 1D-TOCSY experiments.

Based on the magnitude of the coupling constant between $\mathrm{H}-2$ and $\mathrm{H}-3(\mathrm{~J} 13.2 \mathrm{~Hz})$, a pseudo-axial conformation was assigned to H-2. Similar synthetic (S)-2-(phenylethyl)2,3-dihydro-4H-pyran-4-ones showed negative optical rotation, ${ }^{29-31}$ while the $(R)$-2-ethyl-6-methyl-2,3-dihydro$4 H$-pyran-4-one hepialone showed $[\alpha]_{\mathrm{D}}^{20}+106.4$ (c 1.09, EtOH) and positive Cotton effects at 261 and $312 \mathrm{~nm}$ in its CD curve. ${ }^{32}$ Since compound $\mathbf{1}$ showed $[\alpha]_{\mathrm{D}}{ }^{28}-12.9$ and negative Cotton effects at 270 and $318 \mathrm{~nm}$, the structure could be established as (S)-2-(4-hydroxyphenylethyl)6-methyl-2,3-dihydro-4H-pyran-4-one. This is the first time that a pyranone, isolated from a natural source, with this carbon skeleton is being described in the literature.

A molecular formula $\mathrm{C}_{17} \mathrm{H}_{11} \mathrm{NO}_{7}$ was determined for 5 based on the HRMS spectra, which showed peak at $\mathrm{m} / \mathrm{z} 342.0610[\mathrm{M}+\mathrm{H}]^{+}$(calcd. for $\mathrm{C}_{17} \mathrm{H}_{12} \mathrm{NO}_{7}$,

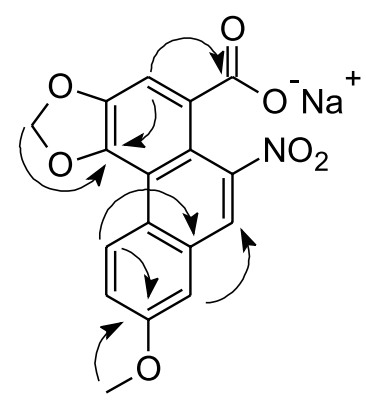

8

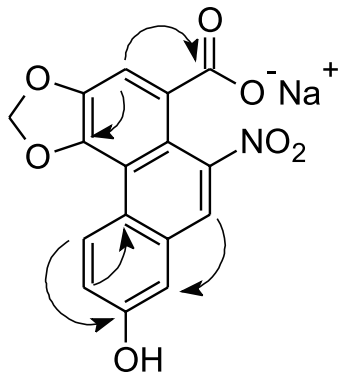

9

Figure 1. Select HMBC $(\rightarrow)$ correlations and ${ }^{1} \mathrm{H}-{ }^{1} \mathrm{H}$ COSY $(\leftrightarrow)$ interactions for $\mathbf{1}, \mathbf{5}, 8$ and $\mathbf{9}$. 
342.0613). The FTIR spectrum of this compound showed characteristic absorption bands to carboxylic acid at 1699 and $2800-3500 \mathrm{~cm}^{-1}$, and to nitro group at 1340 and $1521 \mathrm{~cm}^{-1}$. The ${ }^{1} \mathrm{H}$ and ${ }^{13} \mathrm{C}$ NMR, HMBC and HSQC spectra (Table 1) of a mixture comprising compounds $\mathbf{5}+\mathbf{4}(2: 1)$ showed signals for aristolochic acid I (4) which were identified with those of authentic sample. In addition, these spectra showed signal for 14 aromatic carbons, one acyl $\left(\delta_{\mathrm{C}} 168.5\right)$, one methylenedioxyl $\left(\delta_{\mathrm{H}} 6.46 \mathrm{~s}, 2 \mathrm{H}, \delta_{\mathrm{C}} 103.2\right)$ and one methoxyl $\left(\delta_{\mathrm{H}} 3.94 \mathrm{~s}, 3 \mathrm{H}, \delta_{\mathrm{C}} 56.0\right)$ groups. The ${ }^{1} \mathrm{H}$ NMR spectrum of 5 showed, in the aromatic region, a trisubstituted system with three mutual coupled ABX pattern signals at $\delta 8.99$ $(\mathrm{d}, 1 \mathrm{H}, J 9.0 \mathrm{~Hz}), 7.51(\mathrm{dd}, 1 \mathrm{H}, J 9.0,2.4 \mathrm{~Hz})$, and $7.79(\mathrm{~d}$, $1 \mathrm{H}, J 2.4 \mathrm{~Hz}$ ), which were assigned to $\mathrm{H}-5, \mathrm{H}-6$ and $\mathrm{H}-8$, respectively. In addition, two aromatic $\mathrm{CH}$ were observed in these spectra $\left(\delta_{\mathrm{H}-2} 7.72 \mathrm{~s}, \delta_{\mathrm{C}-2} 111.5\right.$ and $\delta_{\mathrm{H}-9} 8.47 \mathrm{br} \mathrm{s}, \delta_{\mathrm{C}-9}$ 125.5). These data and the UV absorption at 264,308 and $380 \mathrm{~nm}$ are in accordance with a nitrophenanthrene structure, such as shown by aristolochic acids..$^{33}$ The substituent positions on the AA structure were assigned with the help of HMBC experiments (Figure 1). These experiments showed correlations between H-2 $\left(\delta_{\mathrm{H}} 7.72\right)$ and C-11 $\left(\delta_{\mathrm{C}}\right.$ 168.5) confirming the acyl group position in the structure, between $\mathrm{H}-9\left(\delta_{\mathrm{H}} 8.47\right)$ and $\mathrm{C}-8\left(\delta_{\mathrm{C}} 111.6\right)$, as well as $\mathrm{H}-5\left(\delta_{\mathrm{H}} 8.99\right)$ and $\mathrm{OC}_{3}\left(\delta_{\mathrm{H}} 3.94\right)$ and $\mathrm{C}-7\left(\delta_{\mathrm{C}} 159.3\right)$. These latter correlations are also in accordance with a methoxyl group linked to $\mathrm{C}-7$ on the $\mathrm{C}$ ring. Thus, this new compound was determined as 7-O-methylaristolochic acid $\mathrm{F}$.
The ${ }^{1} \mathrm{H}$ and ${ }^{13} \mathrm{C}$ NMR spectra of compounds 8 and 9 are very similar to those of $\mathbf{5}$. However, compounds $\mathbf{8}$ and $\mathbf{9}$ showed in their FTIR spectra absorption bands at ca. $1590 \mathrm{~cm}^{-1}$, characteristic of carboxylate instead of carboxylic acid of AAs $\left(1660-1710 \mathrm{~cm}^{-1}\right) .{ }^{34}$ The spectra revealed also absorption bands that indicated the presence of $\mathrm{NO}_{2}$ group (ca. 1350 and $1540 \mathrm{~cm}^{-1}$ ), and for 9 showed absorption band for hydroxyl group at $3240 \mathrm{~cm}^{-1}$. The HRMS spectra of compounds 8 and $\mathbf{9}$ showed peaks for protonated molecules at $\mathrm{m} / \mathrm{z} 364.0428$ and 350.0268 , in accordance with the molecular formulae $\mathrm{C}_{17} \mathrm{H}_{10} \mathrm{NO}_{7} \mathrm{Na}$ and $\mathrm{C}_{16} \mathrm{H}_{8} \mathrm{NO}_{7} \mathrm{Na}$, respectively, and suggest 8 had a methoxyl substituent, whereas $\mathbf{9}$ a hydroxyl in the nitrophenanthrene structure. In addition, the protonated molecule of compound $\mathbf{8}$ is 22 Da higher than $\mathbf{5}$. Thus, a sodium aristolochate derivative could be proposed for 8 and 9. The correlations observed by HMBC experiments between the oxygenated carbons C-4, C-11 and $\mathrm{H}-2, \mathrm{C}-7$ and $\mathrm{H}-5$, as well as C-8 and H-9 corroborate with this suggestion (Figure 1). Comparison of ${ }^{1} \mathrm{H}$ NMR data of $\mathbf{5 , 8}$ and $\mathbf{9}$ confirmed the lower values for $\delta_{\mathrm{H}-9}$ observed for sodium aristolochates than aristolochic acids $\left(\mathbf{5}: \delta_{\mathrm{H}-9} 8.47, \mathbf{8}: \delta_{\mathrm{H}-9} 8.24,9: \delta_{\mathrm{H}-9} 8.37\right){ }^{34}$ Thus, compounds $\mathbf{8}$ and $\mathbf{9}$ were determined as 7-methoxy and 7-hydroxy sodium aristolochates, respectively. Moreover, an analogous acid of $\mathbf{9}$, which is known as aristolochic acid $\mathrm{F}^{33}$ showed NMR data considerably different from those observed for 9.

Table 1. NMR spectroscopic data for compounds $\mathbf{5}, 8$ and $\mathbf{9}$ (14.1 T, DMSO- $d_{6}$ )

\begin{tabular}{|c|c|c|c|c|c|c|}
\hline \multirow{2}{*}{ Position } & \multicolumn{2}{|c|}{5} & \multicolumn{2}{|c|}{8} & \multicolumn{2}{|c|}{9} \\
\hline & $\delta_{\mathrm{C}}$ & $\delta_{\mathrm{H}}(J$ in $\mathrm{Hz})$ & $\delta_{\mathrm{C}}$ & $\delta_{\mathrm{H}}(J$ in $\mathrm{Hz})$ & $\delta_{\mathrm{C}}$ & $\delta_{\mathrm{H}}(\mathrm{J}$ in $\mathrm{Hz})$ \\
\hline 1 & 125.7 & & $\mathrm{a}$ & & 125.3 & \\
\hline 2 & 111.5 & $7.72, \mathrm{~s}$ & 113.9 & $7.61, \mathrm{~s}$ & 111.1 & $7.67, \mathrm{~s}$ \\
\hline 3 & 145.9 & & 145.7 & & 147.4 & \\
\hline 4 & 145.3 & & 143.4 & & 147.5 & \\
\hline $4 a$ & 117.9 & & 117.6 & & 118.1 & \\
\hline $4 b$ & 123.2 & & 122.3 & & 122.0 & \\
\hline 5 & 128.6 & $8.99, \mathrm{~d}(9.0)$ & 128.5 & $8.97, \mathrm{~d}(9.0)$ & 128.8 & $8.92, \mathrm{~d}(9.0)$ \\
\hline 6 & 120.5 & $7.51, \mathrm{dd}(9.0,2.4)$ & 119.5 & $7.44, \mathrm{dd}(9.0,3.0)$ & 120.8 & $7.37, \mathrm{dd}(9.0,1.8)$ \\
\hline 7 & 159.3 & & 158.0 & & 157.8 & \\
\hline 8 & 111.6 & $7.79, \mathrm{~d}(2.4)$ & 111.0 & 7.69, br s & 114.0 & $7.50, \mathrm{~d}(1.8)$ \\
\hline $8 a$ & 131.1 & & 130.5 & & 131,2 & \\
\hline 9 & 125.5 & 8.47 , br s & 123.8 & 8.24 , br s & 125.2 & 8.37, br s \\
\hline 10 & 146.3 & & 146.6 & & 146.1 & \\
\hline $10 \mathrm{a}$ & 116.1 & & 117.3 & & 115.9 & \\
\hline 11 & 168.5 & & 168.0 & & 168.7 & \\
\hline $\mathrm{OCH}_{2} \mathrm{O}$ & 103.2 & $6.46, \mathrm{~s}$ & 101.6 & $6.36, \mathrm{~s}$ & 103.0 & $6.44, \mathrm{~s}$ \\
\hline $\mathrm{OCH}_{3}$ & 56.0 & $3.94, \mathrm{~s}$ & 55.8 & $3.91, \mathrm{~s}$ & & \\
\hline
\end{tabular}

Signal not observed. 


\section{Conclusions}

To date, 35 different compounds have been isolated from A. urupaensis, including the new 2,3-dihydro$4 H$-pyran-4-one (1). Compounds with this pyranone carbon skeleton have not been isolated from natural sources yet. The new compounds $\mathbf{5 , 8}$ and $\mathbf{9}$ are aristolochic acid derivatives with unusual C-7 oxygenated substituents, and the compounds 21-23, 26 and 35 are being reported for the first time in the Aristolochiaceae family.

\section{Supplementary Information}

Supplementary information (1D and 2D NMR, MS and FTIR spectroscopic data of compounds $\mathbf{1 ,}, \mathbf{5}, \mathbf{8}$ and $\mathbf{9}$ ) is available free of charge at http://jbcs.sbq.org.br as PDF file.

\section{Acknowledgments}

The authors thank Dr Vinicius C. Souza and MSc Joelcio Freitas for plant identification, and FAPESP, CAPES and CNPq for financial support and fellowships to L. M. X. L. and J. C. H.

\section{References}

1. Freitas, J.; Lírio, E. J.; González, F.; Phytotaxa 2013, 124, 55.

2. http://floradobrasil.jbrj.gov.br/reflora/floradobrasil/FB15749, accessed in January 2017.

3. Lopes, L. M. X.; Nascimento, I. R.; Silva, T. D.; Res. Adv. Phytochem. 2001, 2, 19.

4. Heinrich, M.; Chan, J.; Wanke, S.; Neinhuis, C.; Simmonds, M. S. J.; J. Ethnopharmacol. 2009, 125, 108.

5. Chen, C.-H.; Dickman, K. G.; Moriya, M.; Zavadil, J.; Sidorenko, V. S.; Edwards, K. L.; Gnatenko, D. V.; Wu, L.; Turesky, R. J.; Wu, X.-R.; Pu, Y.-S.; Grollman, A. P.; Proc. Natl. Acad. Sci. U. S. A. 2012, 109, 8241.

6. Michl, J.; Kite, G. C.; Wanke, S.; Zierau, O.; Vollmer, G.; Neinhuis, C.; Simmonds, M. S.; Heinrich, M.; J. Nat. Prod. 2016, 79, 30.

7. Michl, J.; Ingrouille, M. J.; Simmonds, M. S. J.; Heinrich, M.; Nat. Prod. Rep. 2014, 31, 676.

8. Zhang, Y.-T.; Jiang, J.-Q.; Helv. Chim. Acta 2006, 89, 2665.

9. Nascimento, I. R.; Lopes, L. M. X.; Phytochemistry 2003, 63, 953.

10. Akasu, M.; Itokawa, H.; Fujita, M.; Tetrahedron Lett. 1974, 15 , 3609 .
11. Wu, T.-S.; Leu, Y.-L.; Chan, Y.-Y.; J. Chin. Chem. Soc. 2000, 47, 221.

12. Priestap, H. A.; Phytochemistry 1985, 24, 849.

13. Tsuruta, A. Y.; Bomm, M. D.; Lopes, M. N.; Lopes, L. M. X.; Eclet. Quim. 2002, 27, 1.

14. Ma, J.; Jones, S. H.; Marshall, R.; Johnson, R. K.; Hecht, S. M.; J. Nat. Prod. 2004, 67, 1162.

15. Dayun, Z.; Baode, W.; Baoshan, H.; Rensheng, X.; Yunping, Q.; Xiuzhen, C.; Dejian, Q.; Acta Chim. Sin. 1983, 41, 74.

16. Holzbach, J. C.; Lopes, L. M. X.; Molecules 2010, 15, 9462.

17. Byun, E.; Jeong, G.-S.; An, R.-B.; Min, T. S.; Kim, Y.-C.; Arch. Pharmacal. Res. 2010, 33, 67.

18. He, D.; Huang, Y.; Ayupbek, A.; Gu, D.; Yang, Y.; Aisa, H. A.; Ito, Y.; J. Liq. Chromatogr. Relat. Technol. 2010, 33, 615.

19. Moriyama, H.; Iizuka, T.; Nagai, M.; Yakugaku Zasshi 2001, 121, 817.

20. Refaat, J.; Samy, M. N.; Desoukey, S. Y.; Ramadan, M. A.; Sugimoto, S.; Matsunami, K.; Kamel, M. S.; Med. Chem. Res. 2015, 24, 2939.

21. Wu, T.; Kong, D. Y.; Li, H. T.; Acta Pharm. Sin. 2004, 39, 534.

22. Sawasdee, K.; Chaowasku, T.; Likhitwitayawuid, K.; Molecules 2010, 15, 639.

23. Salum, M. L.; Robles, C. J.; Erra-Balsells, R.; Org. Lett. 2010, 12, 4808 .

24. Huang, S.-X.; Liao, X.; Nie, Q.-J.; Ding, L.-S.; Peng, S.-L.; Helv. Chim. Acta 2004, 87, 598.

25. Carta, F.; Vullo, D.; Maresca, A.; Scozzafava, A.; Supuran, C. T.; Bioorg. Med. Chem. 2013, 21, 1564.

26. Ciuffreda, P.; Casati, S.; Manzocchi, A.; Magn. Reson. Chem. 2007, 45, 781.

27. Chen, J.-J.; Yang, C.-S.; Peng, C.-F.; Chen, I.-S.; Miaw, C.-L.; J. Nat. Prod. 2008, 71, 1016.

28. Reich, H. J.; Simulating NMR Spectra with WINDNMR-Pro; University of Wisconsin; http://www.chem.wisc.edu/areas/ reich/plt/windnmr.htm, accessed in March 2017.

29. Reiter, M.; Ropp, S.; Gouverneur, V.; Org. Lett. 2004, 6, 91.

30. Zipp, G. G.; Hilfiker, M. A.; Nelson, S. G.; Org. Lett. 2002, 4, 1823.

31. Denmark, S. E.; Heemstra, J. R.; J. Org. Chem. 2007, 72, 5668.

32. Kubo, I.; Matsumoto, T.; Wagner, D. L.; Shoolery, J. N.; Tetrahedron Lett. 1985, 26, 563.

33. Cai, Y.; Cai, T.-G.; Chem. Pharm. Bull. 2010, 58, 1093.

34. Leu, Y.-L.; Chan, Y.-Y.; Wu, T.-S.; Phytochemistry 1998, 48, 743.

Submitted: December 21, 2016 Published online: March 27, 2017 